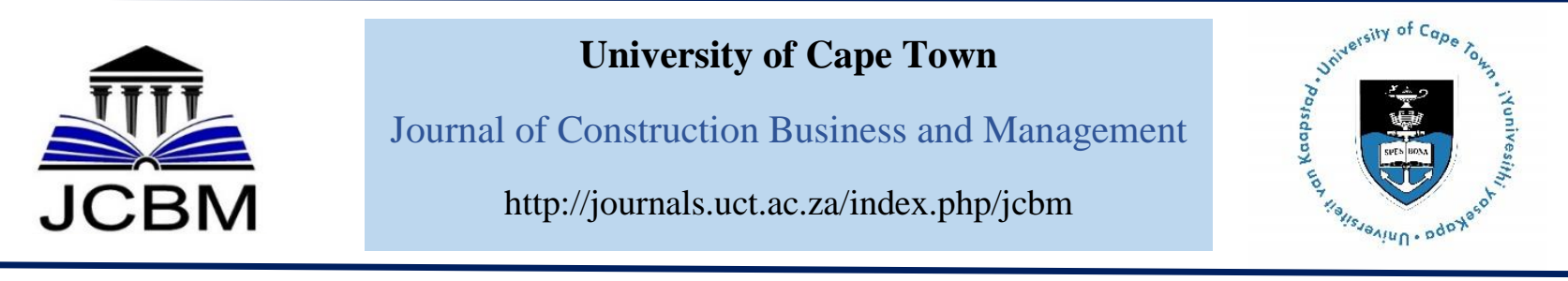

\title{
Influence of the Management Styles and Quality of Management on Project Delivery
}

\author{
A. O. Aiyetan ${ }^{1}$ \\ ${ }^{1}$ Department of Construction Management and Quantity Surveying, Durban University. of Technology, South Africa
}

Received 9 November 2016; received in revised form 19 April 2017, 6 September 2018; accepted 2 October 2018. https://doi.org/10.15641/jcbm.3.1.2019.65

\begin{abstract}
Construction projects differ in features and complexity to each passing decade. Therefore, control is a fundamental requirement to avoid overruns of key performance parameters. The study aims to identify influencing factors of management practices and quality of management during construction on project delivery time to mitigate their impact. The inferential statistic was used in the analysis of data for the study. The sample population consists of architects; builders; quantity surveyors; structural engineers, and clients, totalling eighty-eight (88). The metropolitan cities of five provinces constituted the geographical delimitation of the study. The provinces are Eastern Cape; Free State; Gauteng; KwaZulu-Natal, and Western Cape, while the metropolitan cities are Bloemfontein; Cape Town; Durban; Johannesburg, and Port Elizabeth. The probability sampling method was employed in the selection of architects, South African property owner's, and masters builders. While stratified sampling was used for quantity surveyors. A questionnaire survey was conducted among these stakeholders in the Building Construction Industry to access influencing factors of management style and quality of management during construction. Finding relative to management style include that set time limits, specify goals people are to accomplish and require regular reporting on progress and for quality of management during construction are effectively coordinating resources, developing an appropriate organizational structure to maintain workflow influences project delivery time In most cases these tradesmen require supervision construction, which results in delay and attending, may drastically reduce delay on projects. Based on the finding of the study, ways to mitigate poor management style and quality of management during construction were suggested.

Keywords: Construction, Delivery time, Management style, Quality.
\end{abstract}

\section{Introduction}

Construction involves a lot of tasks, which are executed by tradesmen. In most cases, these tradesmen require supervision to deliver the work according to specification and quality. The extent of management of these tradesmen concerning the level of control given and management style will determine the quality of product and productivity level. Management style dictates the quality of the product, as happy workers engender commitment to work, leading to high productivity and quality. It is in the interest of the contractor to keep workers happy; else the contrary has an adverse effect on the delivery of the project, such as delay. Gonzalez et al. (2016) state that delays can lengthen schedules, increase project costs, and jeopardise quality and safety. Generally, workers do not want to be coarse to work. There is a need to balance supervision with the management style being adopted to achieve the optimum level of production and quality. Accidents on sites are common occurrences (Yilmaz, 2015). Planning against their occurrence is important. The consequences of accidents are adverse relative to project delivery, final cost figure, the company's image and competitive advantage, and the client's finances are always affected. On the part of the industry, the public impression is that of a hazardous industry, which leads to low entrants into the industry at all levels, with the most effect on skilled labour, resulting in shortages. The objectives of this paper are to assess the influence of management styles and qualities on project delivery time in South Africa.

First, a literature review of relevant concepts is presented in Section 2. Section 3 presents the research methodology for the study. This is followed by the presentation of results and discussion of findings in Section 4 . The paper ends by identifying further research

\footnotetext{
${ }^{1}$ Corresponding Author.

Email address: Ayodejia@dut.ac.za
} 
areas and drawing conclusions on the findings of the study.

\section{Literature Review}

\subsection{Project Delivery Time and Project Duration}

It is intended for every project to start, finish and use for its intended purpose and afterwards it is demolished. Project delivery time is the time it takes from commencement to the handing over of key or the project to the client (Darwish, 2017). Project duration is the initial completion time agreed to while awarding the contract for the project, stemming from the master schedule of works submitted by the contractor (Acebes et al., 2015). Project delivery time is different from project duration in that project delivery time encompasses the time for mobilisation of the project team and resources, project duration, and defect liability period (Atkinson, 1999; Darwish, 2017). According to Acebes et al. (2015), project duration is critical to project delivery time because any increase in the project duration will lead to an increase in the project delivery time.

\subsection{Management Style}

Management style deals with the personal attributes possessed by the manager in managing an organisation along with the leadership style. Managers operate within an organisation and manage the functions of an organisation. These attributes possessed by managers that enable them to succeed are called competency. Rees and Porter (2001) define competence as the skills or knowledge possessed by individuals that allows them to manage an organisation successfully. Smallwood (2006:3) states that competencies can be divided into two categories: threshold or surface, which are required to be minimally effective and differentiating or core, a yardstick for superior performers. These are the competitiveness factor (Orozco et al., 2011).

The threshold or surface competencies are Knowledge - information regarding content, and Skills - the ability to perform a task. According to Singh (2004), competences predict performance. Goals need to be defined before actions are taken and performance measured. There are three types of goals, Organisation-wide goals - these include objectives about future directions for large segments of the organisation population; Task-oriented goals - which are specific objectives assigned to an individual or small group of individuals; and Personal goals or level of aspirations - these are goals set by the individuals themselves.

Fryer (2004) points out that lots of leadership studies have taken account of the leader's competence or ability, either in the limited sense of technical knowledge or the broader understanding of competence to lead. For effective and efficient management of human resources, both the technical ability and competence to lead must be employed and could be referred to as management practice. The technical ability concerns laying down construction methods and drawing up of the schedule of works. The competence to lead refers to the motivation and support given to workers.

Griffith and Watson (2004) identify three leadership styles. Autocratic leaders give orders which they insist shall be obeyed; determine policies for the group without consulting it; provide no detailed information about future plans but merely tell the group what immediate step it must take; give personal praise or criticism to each member on their own initiative and remain aloof from the group for the greater part of the time; Democratic leaders give orders only after consulting the group; see to it that policies are worked out with the acceptance of the group (this is critical for effective implementation); never ask people to do things without sketching out the long-term plans on which they are to work; make it clear that praise or blame is a matter for the group and participate in the group as a member, and Laissez-faire leaders do not lead, but leave the group entirely to itself and do not participate.

\subsection{Management Styles of Construction Managers}

According to Burke and Barron (2007), management styles refer to the characteristics, attributes, and skills of construction managers. Although management and leadership are unique systems of action, they are also complimentary. The management styles of construction managers are reinforced and balanced with leadership styles to successfully operate in the complex project environment (Toor and Ofori, 2008). These management styles are identified and summarised in the following subsections.

Pheng and Chuan (2005) state that the definition of goals affects project performance positively. The overall goal of an activity must be set out for each. This will be the driving force for day-to-day achievement and overall accomplishment of the goal. Goal-setting can inspire and motivate subordinates, especially if their performance is linked to remuneration. It also provides an effective means of evaluation and control (Du Toit et al., 2007). Additionally, when staff participate in the decisionmaking process of the organisation, it creates a sense of belonging which leads to individuals paying greater attention to their jobs. These create an environment conducive for work, resulting in high productivity.

One of the factors influencing performance in construction projects is the sequencing of work and the allocation of crew sizes. Rojas and Aramvareel (2003) are of the opinion that out-of-sequence scheduling of work may result in a loss of momentum (rhythm). Walker and Shen (2002) suggest that contractor-related factors such as poor site management and supervision are significant causes of delays in project delivery. Lack of organisation creates a situation of confusion and chaos, a situation in which no meaningful progress can be made. A site that is well laid out, in which offices, storage, and workspaces are well defined, aids the smooth flow of work.

For the achievement of targeted production, time limits should be set for each task to be carried out. A bricklayer has a certain number of bricks to lay per day, depending on the type of brick. A fitter has a certain amount of tonnes/kilograms of steel to bend or cut for a day's wage, and this applies to all trades. Based on this analogy, timelines are set for the achievement of each activity to avoid delay as clear time-lines promote more efficient and goal-driven work.

Managers or site engineers provide specific guidance on what must be done and how it must be done. Bassioni 
et al. (2005) acknowledge that one factor that enhances performance is the development of the organisation's mission, vision and values by a leader and communication of these attributes to the workforce. Pheng and Chuan (2005) conclude that thirteen factors negatively affect project performance, among which is, the non-availability of information. When this is lacking errors may occur, which may lead to poor workmanship and repetition of work. When these situations arise, the project suffers delays.

Edum-Fotwe and McCaffer (2000) identify management skills such as time management and leadership as having a positive effect on construction project delivery. Chan et al. (2004) argue that a project leader's commitment to time affects the delivery of a construction project. A work schedule is a tool that is used to monitor the progress of work. To avoid delays in project delivery, the performance of the project should be evaluated regularly on this through work schedule. This helps in identifying areas of poor performance so that the reasons for this lag in

Management of an organisation should not only be concerned about work performance but also staff welfare. Management should not turn a blind eye to staff challenges. There should be a means for the personal challenges of workers to be made known to management. The labourers and skilled labour are those who perform construction activities with guidance from management staff; therefore their health is crucial to the speedy completion of a project. All the factors discussed above are those that create job satisfaction and boost productivity.

\subsection{Quality of Management During Construction}

Many factors affect quality, which impedes on the construction speed of a contractor. Aiyetan (2011) gives a listing while Ponpeng and Liston (2003) conclude that the factors outlined in the following sub-sections are criteria that determine contractor's ability to deliver a project with regards to acceptable quality standards.

Scheduling of activities using the Gantt chart is an aid for an operative, smooth flow and monitoring of works during the construction stage. Arditi and Mohammadi (2002) state that timeliness is the completion of the contract as planned, and with high accuracy. That is, the ability to execute the work regarding the correct specification and quality are good indicators of a contractor's expertise.

The key parameters of delivering a project are quality, time, and cost. Therefore, it is important to analyse the various construction methods as against the volume and complexity of work. This is done, in order, to select the best delivery solution for the project. While bearing in mind the key performance parameters in doing this. Belout and Gauvreau (2003) and Proverb and Holt (2000:2) also share this view

One of the factors that may contribute to project delay is access to and from the site. A bad road surface to the site will cause vehicles to break down and result in late delivery. Materials need to be moved from one point to another on site. For example, from production point to place of incorporation on the project. Difficulty in the movement of materials will lead to late supply and ultimately result in delayed delivery of the project. This is further buttressed by Koushki and Kartam (2004) declaring that late delivery and damaged materials to site cause project delays. Besides, Pertula et al. (2003:10) report that a total of 2945 disability days were experienced on a project over a period of eighteen months, which is traceable to accidents resulting from materials handling on site.

This refers to the chronology of work execution. The planning of activities as they should flow to avoid stoppages. The identification of the critical path contributes immensely to achieving work sequencing and maintenance of workflow. Fox et al. (2003) state that construction processes should be assessed before implementation.

The continual updating of the schedule and planning afford the opportunity of keeping the project on track. Lee et al. (2004) cite Lantelme and Formoso (2000) who declare that measurement-managed companies have proven better performance compared to their nonmeasurement counterparts. Pongpeng and Liston (2002) identify criteria for contractors' ability to perform with regards to a project, that monitoring is one out of five most important factors.

A project will take a longer time to complete compared with the initially planned time if activities are repeated (Hardie, 2001). The causes of these problems are the poor quality of workmanship and poor quality of material usage. The ability to quickly resolve and recover from these problems on a project is a good quality relative to the project manager. Dainty et al. (2004) specify qualities for successful project completion that a project must possess, which include analytical thinking power, information seeking and initiative. These will enhance problem-solving on site. Scott-Young and Samson (2007) postulate that there is a direct and positive relationship between effective team problem-solving and project outcomes.

The effective layout of a site is very important and afford minimum travel time and movement of materials, plant and labour (Tam et al., 2002). Different authors have varying views concerning the coordination skills of a project manager. Chan et al. (2004) note that it affects the construction of the project. Kazaz and Ulubeyli (2003) declare that the assignment of resources determines the overall duration and cost of the project. Therefore, to overcome this, there must be a good inventory system in place. Material movement schedule should be developed to monitor levels of materials at any time, to ensure a continuous flow of activities. Also, Jha and Iyer (2005) affirm that coordination among project participants and resources positively influence project delivery.

Bassioni et al. (2005) are of the view that the involvement of leaders in ensuring that management systems are developed for operations is a significant performance factor for success. For operations to flow smoothly and ensure its successful delivery, there should be a good system in place concerning command and information dissemination. Activities are executed based on information given and relative to the next operation, the quantity of materials and work crew supply. Therefore, an organogram concerning hierarchy in an organisation is needful and will assist in this regard. 


\section{Research Methodology}

A study titled influence of management style and quality during construction was conducted at the Nelson Mandela Metropolitan University, Port Elizabeth in South Africa, to identify and assess factors influencing the delivery of project concerning these factors. The study focussed on project duration. The research methodology consists of five parts; an in-depth review of related literature; the research design; findings and discussion; conclusions and recommendations, and references. The sampling frame consist architects 1149 (obtained from the South African Institute of Architects (SAIA)); Master Builders 320 (obtained from the Master Builder's Association (MBA)); clients 161 (obtained from the South African Property Owners Association (SAPOA)); structural engineers 43 (obtained from Civil Engineers' South Africa (CESA East Cape)), and quantity surveyors 473 (obtained from the Association of South African Quantity Surveyors (ASAQS)). From these, the sample sizes were calculated.

Probability sampling technique was employed for sample selection. For the Architects, Master Builders, and the Clients random sampling was used. Systematic sampling techniques were used for the quantity surveyors, and the structural engineers and other the entire sample were surveyed based on the recommendation of Leedy and Omrod (2014). The research instrument for this study was a questionnaire survey, which was administered to respondents through the post (Architects, Master Builders, Structural engineers, SAPOA and CESA) and email (Quantity Surveyors).

Based on Griffith and Watson's categorization of leadership styles, nine (9) management styles (Set timelines, Specify goals people are to accomplish, Require regular reporting on progress, Provide specific direction, Organise the work situation for workers, Involve team members through discussion of work, Provide support and encouragement, Allow the workers to organize the work, Seek worker's opinion and concerns) were identified and presented to the respondents to indicate their influences on project delivery time. The responses were received through the same means. The questionnaire response rate according to professional obtained is architects (9), master builders (18), quantity surveyors (23), and structural engineers (23), clients (12) and others (3). A total of eighty-eight (88) questionnaires are representing $6.1 \%$ response rate achievement recorded on questionnaire administration.

The data obtained were analysed using descriptive and Inferential statistical techniques. A five-point Likert scale adjoined with 'Unsure' and 'Does not' (DN) options were employed to analyse summated scores of the respondent's responses. Given that there are five points on the scale, and that $5-1=4$, the ranges were determined by dividing four by five which equates to 0.8 . Consequently, the scales and their definitions are given as follows:

- $4.20 \leq 5.00$ between a near major to major/major influence;

- $\quad>3.40 \leq 4.20$ between moderate influence to a near major / near major influence;

- $\quad>2.60 \leq 3.40$ between a near minor to moderate influence / moderate influence;
- $\quad>1.80 \leq 2.60$ between a minor to near minor influence / near minor influence, and

- $\quad>1.00 \leq 1.08$ between a minor to near minor influence.

Cronbach's coefficient test and validity test were performed and were found satisfactory. Cronbach's alpha of $\geq .97$ and factor loading of $>.60$ for samples sizes 85 89 were obtained. Based on these data obtained can be deemed reliable. It was found that majority of the respondents belong to the private sector $(74 \%)$, their average working years is 17 , and most are over the age of thirty (30). Respondents with Bachelor's degree predominate $(25 \%)$, and who have handled not less than six (6) types of projects.

\section{Findings and Discussion}

\subsection{Influence of Management Styles on Project Delivery Time}

The study sought to find out the influence of management styles on project delivery time. The data collected in this regard is presented in Table 1 .

Table 1: Mean score of the influence of management styles on project delivery time

\begin{tabular}{lc}
\hline Management styles adopted & Mean score \\
\hline Set timelines & 4.13 \\
\hline Specify goals people are to accomplish & 4.06 \\
\hline Require regular reporting on progress & 3.97 \\
\hline Provide specific direction & 3.96 \\
\hline Organise the work situation for workers & 3.79 \\
\hline $\begin{array}{l}\text { Involve team members through discussion } \\
\text { of work }\end{array}$ & 3.93 \\
\hline Provide support and encouragement & 3.85 \\
\hline Allow the workers to organise the work & 3.79 \\
\hline Seek worker's opinion and concerns & 3.54 \\
\hline
\end{tabular}

Table 1 presents the respondents' rating of the influence of management styles on project delivery time in South Africa. It is notable that all factors in this category have mean scores is $3.40<$ Mean Score<4.20, which indicates that these factors have between a moderate to near major / near major influence on project delivery time. Nine (9) management styles were presented to the respondents for rating; out of which four (Set timelines, Specify goals people are to accomplish, Require regular reporting on progress, Provide specific direction) were derivatives of autocratic leadership styles, three (Organise the work situation for workers, Involve team members through discussion of work, Provide support and encouragement) were derived from democratic leadership styles, and two (Allow the workers to organize the work, Seek worker's opinion and concerns) from laissez-faire leadership styles. Table 1 shows that management styles derived from autocratic leadership styles were found to have the most influence on project delivery time (Mean Score is from 3.96 to 4.13). Among the autocratic-based management styles, the most influential management styles on project delivery time are setting timelines.

This finding is close in agreement with previous studies by Rojas and Aramvareel (2003) that out-ofsequence scheduling of work may result in a loss of 
momentum (rhythm) per time and subsequently lost in production. This implies that to achieve meaningful progress, managers need to define the number of tasks to be performed within a specified time. Also, the result shows that the lack of specification of timelines for the performance of activities may have an adverse effect on the delivery of projects. Construction activities have been described as difficult and masculine. Therefore, to meet production targets, measures such as setting timelines are set to achieve planned production levels.

The next significant management style among the autocratic-based management styles is specifying the goals that people are to accomplish. Construction projects consist of activities, which need to be specified to workers and supervisors through information given by management for monthly, weekly or daily task executions until project completion. This is partly the reason for the need to provide a work schedule. When these details are not adhered to, it may have an adverse effect on the delivery time of projects. This agrees with the conclusion of Pheng and Chuan (2005) that the definition of goals affects project performance positively.

Require regular reporting on progress and Provide specific direction only have a moderate influence on project delivery time. A progress report is a project control system, and when the project delivery time is being monitored and controlled effectively, the chance of timely delivery is high. All the three democratic-based management styles have a moderate influence on project delivery time (Organise the work situation for workers (Mean Score=3.79), Involve team members through discussion of work (Mean Score=3.93), Provide support and encouragement (Mean Score $=3.85)$ ). This shows that the efforts by construction managers to organise tasks, involve the workers in the organisation of works, and encourage workers, contribute positively to the project delivery time. It is deduced from this result that workers value the encouragement and involvement in work planning and organisation.

The least influential management styles are found in laissez-faire-based management styles category (Allow the workers to organise the work (Mean Score=3.79), Seek worker's opinion and concerns (Mean Score=3.54)). This shows that although it is important to involve the workers in work planning, it is detrimental to the project objectives and expectations to allow the workers to be in control of the work planning and organisation. Workers are not very skilful in contributing ideas to improve work execution. Most of the workers are afraid to speak to their supervisors. These are the most likely reasons for this factor having the lowest impact on project delivery time.

\subsection{Influence of Management Qualities on Project Delivery Time}

The study also sought to investigate the influence of management qualities on project delivery time. The data collected in this regard is presented in Table 2.

Table 2: Mean score of the influence of management qualities on project delivery time

\begin{tabular}{lc}
\hline Management styles adopted & Mean score \\
\hline Effectively coordinating resources & 3.92 \\
\hline
\end{tabular}

\begin{tabular}{ll}
\hline $\begin{array}{l}\text { Developing an appropriate organisational } \\
\text { structure to maintain workflow }\end{array}$ & 3.88 \\
\hline $\begin{array}{l}\text { Forecasted planning date - activity duration, } \\
\text { resource quantities required }\end{array}$ & 3.80 \\
\hdashline $\begin{array}{l}\text { Responding to recover from problems or } \\
\text { taking advantage of opportunities presented }\end{array}$ & 3.77 \\
\hline $\begin{array}{l}\text { Monitoring and updating plans to reflect } \\
\text { work status appropriately }\end{array}$ & 3.66 \\
\hdashline $\begin{array}{l}\text { Analysing of work sequencing to achieve } \\
\text { and maintain workflow }\end{array}$ & 3.66 \\
\hline $\begin{array}{l}\text { Analysing resource movement to and on- } \\
\text { site }\end{array}$ & 3.50 \\
\hline Analysing construction methods & 3.38 \\
\hline Effectively coordinating resources & 3.92 \\
\hline Respond
\end{tabular}

Respondents were required to rate the influence of management qualities during construction on project delivery (Table 2). Seven out of eight management qualities have Mean Score $>3.40 \leq 4.20$, which indicates a moderate to a near major / near major influence on project delivery time. The most critical management quality as found in this study is effectively coordinating resources. The lack of effective control of resources, namely machines, materials and human resources may lead to disorder on construction sites. A clash of activities, which may, in turn, lead to a lack of materials on site and a shortage of labour on site, may, in turn, result in low productivity. These all have a cumulative adverse effect on the delivery time of the project. These findings concur with the findings of Chan et al. (2004) and Kazaz and Ulubeyli (2003). Chan et al. (2004) found that the coordinating skills of the project team leader affect the construction of a project and Kazaz and Ulubeyli (2003) are of the view that assignment decisions of resources such as labour, equipment and materials control the overall duration and cost of a project.

The next influential management quality is developing an appropriate organisational structure to maintain workflow. Construction activities are carried out by issuing instructions, and by providing guidance and support. Superiors give instructions to subordinates. The labourers and supervisors must be aware of whom they must take instructions from and whom to report. A situation where these are not well defined may lead to poor performance on the project. A well-defined organisational structure will assist in the maintenance of a steady workflow. This finding is in line with the conclusion of Bassioni et al. (2005) declaring that the involvement of leaders in ensuring that management systems are developed for operations is a significant performance factor for success

The management quality with the lowest mean score is analysing the movement of resources to and from the site. The various resources that are required on site must be estimated to avoid idleness which engenders waste. These could be in the form of time losses, which is indirectly wasting money and may lead to bankruptcy and abandonment of the project.

The findings of this study agree with most results of studies that have been conducted in different countries in the world such as Koushki and Kartam (2004) that show that late delivery and damaged materials to site cause project delays. Pheng and Chuan (2005) found that 
management style adopted adversely affect workers productivity when the specification of goals workers are to achieve are not set. Relative to management quality during construction, inability to effectively coordinate resources were found to have an adverse effect on project delivery time, when adequate measures are not in place to mitigate their impact on project delivery time (Tam et al., 2002); develop appropriate organization structure (Bassiani et al., 2003), and forecasted planning date (Arditi and Mohammed, 2002).

\section{Conclusion and Further Research}

The study reached these conclusions that the following adversely affect project delivery time when attention is not given to them: setting timelines, specifying goals for workers, regular reporting on progress, effectively coordinating resources, developing an appropriate

\section{References}

Acebes, F., Pajares, J., Galan, J.M., and Lopez-Paredes, A. (2015). Exploring the relations between project delivery and activity duration. J.L. Ayuso Munoz et al. (eds.) Project Management and Engineering. DOI 10.1007/978-3-319-12754-5-2.

Aiyetan, A.O. 2011. Influences on Construction Project Delivery Time: Influencing Factors of Delays on Project Delivery. 1st ed VDM Publishing House Ltd., USA.

Andawei, M. M. 2003. Critical Path Method: A tool for project Delay Control. The Quantity Surveyor, 44 (3), 25.

Atkinson, R. (1999). Project management: cost, time and quality, two best guesses and a phenomenon, it's time to accept other success criteria. International Journal of Project Management, 17(6): 337-342.

Bassioni, H. A., Price, A. D. F. and Hassan, T. M. 2005. Building a Conceptual Framework for Measuring Business Performance in Construction: An Empirical Evaluation. Construction Management and Economics, (23), 495-507.

Belout, A. and Gauvreau, C. 2004. Factors influencing project success: The Impact of Human Resource Management. International Journal of Project Management, 22 (1), 1-11.

Burke, R. and Barron, S. (2007). Project management leadership. UK: Burke publishing.

Chan, A. P. C., Scott, D. and Chan, A.P.L. 2004. Factors Affecting The Success of a Construction Project. Journal of Construction Engineering and Management, ASCE 130 (1), 153-155.

Dai, J., Goodrum, P. M. and Maloney, W. 2007. Analysis of Craft Workers' and Foremen's perceptions of the Factors Affecting Construction Labour Productivity. Construction Management and Economics, (25), 11391152.

Dainty, A.R.J., Cheng, M. and Moore, D.R. 2003. Redefining Performance Measures for Construction Project Managers: An Empirical Evaluation. Journal of Construction Management and Economics, (21), 209-218

Darwish, M. (2017). Construction project delivery methods.https://www.researchgate.net/publication/32016 5827_Construction_Project_Delivery_Methods organisational structure to maintain workflow, and forecasting planning date. To mitigate the effect of the findings, it is recommended that weekly planning of resources and optimum gang size should be developed. This is relative to alleviating materials shortages and achievement of the target output of production, selecting adequate gang sizes to the task, and ensuring correct activity sequencing. Identification of key performance factors such as physical and socio-cultural factors that could impede on construction speed is recommended for further research.

\section{Publication}

An earlier version of this paper was presented at the 9th cidb PG Conference, 1-4 February 2016, Cape Town, South Africa.

Edum - Fotwe, F.T. and McCaffer, R. 2000. Developing Project Management Competency: Perspective from the Construction Industry. International Journal of Project Management, 18 (2), 111-124

Fox, S., Marsh, L. and Cockerham, G. 2003. Assessing the Capability of Construction Processes to Realize Building Designs. Construction Management and Economics, (21), 7-10.

Fryer, B. 2004. The Practice of Construction Management. 4th Ed, Oxford: Blackwell Publishing.

Griffith, A. and Watson, P. 2004. Construction Management Principles and Practice, 1st Ed, Palgrave Macmillan, New York.

Gonzalez, P.; Gonzalez, V.; Molenaar, K. Orozco, F. (2016) Analysis of Causes of Delay and Time Performance in Construction Projects. Journal of Construction, Engineering and Management, 140(1).

Hardie, N. 2001. The Prediction and Control of Project Duration: A Recursive Model. International Journal of Project Management (1(0, pp. 401-409.

Jha, K.N. and Iyer, K.C. 2006. Critical Determinants of Project Coordination. International Journal of Project Management, 124 (4), 314-322

Koushki, P. A. and Kartam, N. 2004. Impact of Construction Materials on Project Time and Cost in Kuwait. Engineering, Construction and Architectural Management, 11 (2), 126-132.

Lantelme, E. And Formoso, C. T 2000. Improving Performance Through Measurement: The Application of Lean Production and Organisational Learning

Principles. Proc. IGLC - 8. International Group for Lean Construction, Brington.

Lee, H., Yu, J. and Kim, S. 2004. Impact of Labour factors on Workflow. Journal of Construction Engineering and Management, 130 (6), 918-923.

Leedy, P. D. And Ormrod, J. E. 2014. Practical Research: planning and design. 10th Ed. New Jersey: Pearson Prentice Hall.

Ogunsemi, D. R. and Jagboro, G. O. 2006. Time - Cost Model for Building Projects in Nigeria. Construction Management and Economics, (24), 253 - 258.

Orozco, F., Serpell, A., Molenaar, K., and Forcael, E. 2011. "Modeling Competitiveness Factors and Indexes 
for Construction Companies: Findings of Chile.” Journal of Construction, Engineering and Management.

Perttula, P., Merjuma, J., Kiurula, M. and Laitinen, H. 2003. Accidents in Materials Handling at Construction Sites. Construction Management and Economics, (21), 729-736.

Pheng, L. S. and Chuan, Q. T. 2006. Environmental Factors and Work Performance of Project Managers in The Construction Industry. International Journal of Project Management, 24 (1), 24-37.

Ponpeng, J. and Liston, J. 2003. Contractor Ability Criteria: A Review from the Thai Construction Industry. Journal of Construction Management and Economics, (21), 267-282

Proverbs, D.C. and Holt, G.D. 2000. A Theoretical Model for Optimum Project (Time) Performance Based on European Best Practice. Construction Management and Economics, (17), 652-665.

Rees, W. D. and Porter, C. 2001. The Skill of Management. 5th Ed. Publishers: Thomas learning, London.
Scott-Young, C and Samson, D. 2009. Team Management for Fast Projects: An Empirical Study of Process Industries. International Journal of Operations and Production Management. 29 (6), 612-635.

Sing, T. F. 2002. Time to Build Options in Construction Processes. Construction Management and Economics, (20), 119-130.

Smallwood, J.J. 2006. The Practice of Construction Management. Acta Structilia, 13 (2), 25-42.

Toor, S. and Ofori, G. (2008). Leadership for future construction industry: agenda for autocratic leadership. International journal of project management, 26(6): 620630.

Walker, D. H. T. and Shen, Y. J. (2002) Project Understanding, Planning, Flexibility of Management Action and Construction Time Performance: Two Australian Case Studies. Construction Management and Economics, (20), 31-44.

Yilmaz, F. 2015. Monitoring and Analysis of Construction Site Accidents by using Accidents Analysis Management System in Turkey. Journal of Sustainable Development. 8(2), 57-65. 